\title{
Editorial
}

\section{Introduction: Writing and Viewing Illness}

\author{
Giorgia Alù
}

School of Languages and Cultures, University of Sydney, A18 Brennan MacCallum Building, Camperdown, Sydney NSW 2006, Australia; giorgia.alu@sydney.edu.au

Received: 27 July 2020; Accepted: 14 August 2020; Published: 25 August 2020

\begin{abstract}
Writing (prosaic, non-fictional and (auto)biographical) and photography (as aesthetics and technology, language, material object and practice) can communicate and interrelate in the narration and depiction of physical disorders. The five articles in this Special Issue explore how the body and its pain and disorders can be accessed in projects that either interlace words and images within themselves or that communicate and interrelate with other written or visual texts produced by others. In these photo-textual encounters (or clashes), wounded, tormented, weakened bodies are narrated and mediated, as well as marked, modified and exposed by personal and emotional choices or by ideological and socio-historical circumstances. The articles invite us to reflect on the ideological discourses, issues of power, practice, ethics and agency that any illness implicates, as well as the flexible boundaries of the written and visual language narrating such an overpowering experience.
\end{abstract}

Keywords: illness narratives; autopathography; photography; iconotext; intermediality; medical humanities

Since the 1990s, several academic works have explored the presence of disease (in its many manifestations) in literature (Bevan 1993; Healy 2001; Lawlor 2007), as well as the many forms of narrative about illness (Couser 1997; Avrahami 2007; Jurecic 2012). At the same time, studies in the field of visual culture have investigated how photography has engaged-artistically, scientifically and ethically—with sickness, grief and ailment (Squiers 2005; Burns 2007). The visual medium of photography has been one of the most popular and powerful in exposing bodies that are wounded, in pain, "untypical" and "misbehaving" - two terms used in the context of a recent exhibition on artists Jo Spence and Oreet Ashery at the Wellcome Collection in London (30 May 2019-26 January 2020) - and their relation with the surrounding environment. Nonetheless, the ways in which writing and photography have collaborated, communicated or clashed in the narration of the body and its disorders still needs a full exploration. The five articles in this Special Issue therefore aim to reflect on how writing (prosaic, non-fictional and (auto)biographical) and photography (as aesthetics and technology, language, material object and practice) communicate and interrelate in the narration and depiction of physical disorders. The articles focus on works published and projects produced in the late twentieth and early twenty-first centuries. It is in contemporary representations and narrations in particular that constructed ideas of illness, social stereotypes as well as healthcare regimes and ecology and the economic and political implications related to medicine and science have been questioned and challenged, more so and more intensely than in the past, in part thanks to the advent of innovative narrative methods and sophisticated visual technologies. Artists and writers, for instance, have expanded definitions of illness and searched for new ways to approach the experience through mixed-media narrative modes that have also repositioned personal experiences of ailment and caring within a group or community. Their works connect arts, (bio)medicine and science, while the complexities and limits of telling, showing, reading and viewing trauma and grief are regularly pondered.

By analyzing the works of contemporary artists, writers and practitioners, some of the questions the articles in this Special Issue attempt to answer include: does the author's portrayal of disease unveil 
the limits of words or images in the communication of illness? How is illness domesticated, localized, celebrated and disowned through the multifarious interrelations of the verbal and the visual? How do photographic and written narratives corroborate or subvert notions, as well as specific ideological discourses, related to disease and sickness?

\section{A Multiplicity of Narrations}

At the beginning of the twentieth century, Virginia Woolf lamented that sickness had not been paid enough attention in the literature of the time. In her essay On Being Ill (Woolf 1926), she famously argued that the ordinariness of illness had prevented it from "tak[ing] its place with love and battle and jealousy among the prime themes of literature" (p. 32). Woolf exhorted writers to pay attention to the "daily drama of the body", and the neglected wars fought "in the solitude of the bedroom against the assault of fever or the oncome of melancholia" (p. 32). Although Woolf named "the poverty of the language" as one of "the drawbacks of illness as matter for literature" (p. 34), at the beginning of the twentieth century, artists and writers actually did make the ordinary experience of illness the subject of their works in moderate ways. From the first half of the twentieth century, canonical literary works in which suffering, convalescence, impairment, fear of contagion and medical work are present famously include T. S. Eliot's The Waste Land (1922), Italo Svevo's The Confessions of Zeno (1923), Mikhail Bulgakov's A Country Doctor's Notebook (1925), Alphonse Daudet's In the Land of Pain (1930), Albert Camus's The Plague (1947) and Samuel Beckett's Endgame (1957), just to name a few. In some instances, illness also became an agent of modern literature and acquired an important role in the fashioning of literary figures, as Yudkoff (2018) has demonstrated in the case of modern Jewish writing. At the same time, narratives about illness or so-called "illness narratives" started to appear. Professional medical journals, and occasionally the popular press, began more frequently to publish biographical case studies and professional memoirs written by psychologists, psychiatrists, doctors and nurses. In the 1920s and 1930s, patients' own illness narratives also emerged, as in the case of accounts by tuberculosis patients or what historian Rothman (1994) has labelled "sanatorium narratives", and in the 1950s we find stories written by patients with polio, together with a variety of stories on illness by patients and medical staff in other forms, such as the cinematic (Shell 2005) ${ }^{1}$.

Yet, literature and popular culture have repeatedly tended to translate and reduce illness-both patients' experiences of it and the related medical context-through stereotypes and standardization. In 1978, Susan Sontag, in her Illness as Metaphor, approached literature from the point of view of the sick subject who defied the psychologically, historically and existentially constructed representations of her pain. Sontag-whose own battle against cancer would in turn be recounted in a memoir written by her son and through the photographs of Annie Leibovitz-rebelled against the metaphorical images that linked illness to stereotypes and mystifications and to "punitive or sentimental fantasies" (Sontag 1978, p. 3) associated with this experience. For Sontag, both cancer and, in the 1980s, AIDS (as verbalized in her AIDS and its Metaphors 1989) have been the particular subjects of metaphors, and were considered as something one should hide for fear of contaminating others or endangering someone's life $^{2}$. She notes that "[a]s death is now an offensively meaningless event, so that disease widely considered a synonym for death is experienced as something to hide" (Sontag 1978, p. 8). As a sort of response to the taboos of illness, there arose an increased interest in representations of pain and suffering by people who experienced illness first-hand, by friends, relatives and caretakers and by those merely interested in the topic. Some of the factors that led to this increased interest also included the feminist

1 On cinema and illness (including mental illness), the adaptation of medicine to film, and how television and cinema have contributed to shaping health perceptions, practices and policies, see (Harper and Moor 2005; Reagan et al. 2007; Wijdicks 2020).

2 As Sontag argues in AIDS and its Metaphors (Sontag 1989), during the first years of the AIDS epidemic, media representations contributed to a reinforcement of the idea that the illness was a result of "high risk" behaviour and, therefore, the patient's "fault". 
movement of the late 1970s, the spread of AIDS in the 1980s and 1990s, the emergence of the women's and gay rights movements and disability movements, and medical professionalization and specialization that affected the doctor-patient relationship (Jurecic 2012, p. 2; Bolaki 2016) ${ }^{3}$. Additionally, the field has expanded due to the renewed popularity of life-writing genres, such as memoirs and self-help narratives (Illouz 2008), and has been made more accessible thanks to the prevalence of self-publication and, more recently, digital technologies. In particular, visual and multimodal elements in social media can challenge the function and effects of traditional illness narratives and change the relationship between patients and their conditions (Gonzalez-Polledo and Tarr 2014; Hinson and Sword 2019; Sendra and Farré 2020).

Although canonical literary writing offers the possibility of representing the distressing experience of illness, it is often perceived as insufficient in depicting the nature of physical pain and the dissolution of the self. Because illness changes one's understanding of the world and affects interactions between people as well as between humans and their environment, it requires diverse types of narrative forms and formats. For Sontag (1989), for instance, writing about illness should also be a scientific and intellectual endeavor, rather than simply a literary one. Scholars have, therefore, attempted to place illness narratives in historical and cultural contexts, trying to avoid any adherence to canons or traditional approaches to literature. So, from fiction, poetry and memoirs to popular journalism, science fiction and graphic fiction, illness experiences have found multiple modes and genres in which to be expressed and represented. Indeed, Whitehead endorses the potential of the field "to engage with an expanded notion of literary genre, encompassing more fragmentary or mixed-media narrative modes" that readdress the dominance of realist fiction and autobiography in existing scholarship (Whitehead and Woods 2016, p. 114).

The varied works and intermedial projects examined in the five articles can all be broadly defined as "illness narratives". As a general rule, illness narratives comprise an intersection between (auto)biographical narratives about living with an illness and meditations on the broader implications of the disease, treatment, relations with the medical entourage, recovery and impacts on familial and other relationships (Bolaki 2016, p. 4). Such a definition also includes those varied narratives arising from carers and medical staff. Addressing a more nuanced and complex understanding of illness, these stories are often characterized by irregular structures, fragmentation and discontinuity, or circularity and multiple layers. Kathlyn Conway stresses that in the writing of illness narratives, "writing frustrates as much as it heals" (Conway 2007, p. 3). In fact, during this process, authors often discover that something of the emotional intensity of their condition, of the bodily and psychological devastation and of the damaged sense of self that illness entails is not grasped by language and canonical forms (Conway 2007, p. 3). In particular, serious illness has an indeterminate beginning and an unknown ending, so although the experience can be told chronologically, it often requires that the real focus be on "the ill person's internal experience as it unfolds outside of time" (Conway 2007, p. 99). Moreover, medical discourse implies a narrative sense of time and self that does not correspond to the patient's experience. The inescapable chronology of the accident or diagnosis, meetings with doctors, treatments, and finally the restoration to health or the acceptance of death lead narrators to experiment with language and narrative forms and formats in the attempt to provide the essence of their far more complex experience (Conway 2007, p. 13), or to declare the impossibility of such an attempt.

Autobiographical narration can disclose the role of bodily transformations in self-examination and in the practice of self-reconstruction. For Couser, "autobiographical narrative of illness or disability," or "autopathography," can heighten one's awareness of vulnerability and one's "consciousness of self and of contingency" (Couser 1997, p. 5; see also Couser 1991; other studies include (Bell 2006;

3 Ann Jurecic reminds us of how the 1918-1919 influenza virtually disappeared from British and American literature. Its vanishing from popular consciousness contrasts with the literary reaction to the emergence of HIV/AIDS in the 1980s and 1990s (Jurecic 2012, pp. 1-17). A recent study that explores the presence of 1918-1919 influenza pandemic in British, Irish and American literature is Outka (2020). 
Loewenthal 2013). At the same time, the illness narrative can be a defense against mortality and, whatever the ending, it can be perceived as a kind of "triumph narrative" (Conway 2007, p. 20). Although "autopathographies" include discussions of medical conditions and treatments, their focus is on survival and on the reclaiming of the body from the depersonalization of medical discourses and the social stigmatization of illness. As a matter of fact, in The Wounded Storyteller, Frank (1995, pp. 10-13) views contemporary illness narratives as a postmodern phenomenon representing the patient's reclaiming of his or her own voice within — and gaze upon — the medical dialogue (see also (Scarry 1985; Avrahami 2007; DasGupta and Hurst 2007)) ${ }^{4}$. These narratives include memoirs (and other forms of life writing) by those who look after the sufferer: the onlookers and carers who also become entangled in the administration, time, idioms and prognoses of the medical discourse.

Nevertheless, narrating illness is an ethical act, and, to use Adriana Cavarero's words on auto/biographical writing, it implies "an ethic of the gift" (Cavarero 2000, p. 3) in the sense that it involves the act of donating one's own life story to others, and implies a political and ethical responsibility in exposing one's own or others' troubled existences (Cavarero 2000, p. 3). Issues of responsibility are critical when stories can have the effect of accentuating the vulnerability of ill subjects. Narrating physical disorders does not only function pedagogically or therapeutically, but it also aims to make an ethical appeal to the readers and viewers (see (Jurecic 2012, p. 12)) who use narratives of illness "to make meaning of the experiences of living at risk, in prognosis, and in pain" (Jurecic 2012, p. 4). Moreover, narrating and reading illness narratives "creates ethical and emotional engagement in a way that affords something beyond a sense of the indeterminacy of meaning" (Avrahami 2007, p. 4), and that can interconnect individuals (the patient, the doctor or nurse and the caregiver) with a wider community. These narrations also create collaboratively performed events through which authors or artists and readers/viewers commit themselves to reflect on the political and socio-economic implications of telling and displaying illness and physical disorders.

As another consequence of such a shared engagement, illness and physical disorders resist being tied to a single medium. Stella Bolaki argues that "illness narratives" are characterized by multiplicity and a refusal of categorizations: narratives of illness encompass "the multiplicity of illnesses and their treatments; the different arts and media that need to be included in the field; and finally, the range of methods that will foster a more critical engagement with health, medicine and culture" (Bolaki 2016, pp. 7-8). By affecting diverse fields-from medicine and science to anthropology, media, sociology, literary studies and the arts-illness, therefore, makes the inclusion of its narratives into specific and exclusive spheres incongruous (Diedrich 2007; Squier 2007; Radley 2009; Jurecic 2012; Bolaki 2016) $)^{5}$. The articles presented here therefore aim to demonstrate how writing, showing, reading and seeing illness expands disciplinary borders and incites connections between diverse subjects, texts and cultural practices.

\section{Disorders between Words and Images}

While writing is seldom satisfactory for expressing the complex effects of physical and psychological distress and pain, photographs, on the other hand, can provide indirect visual evidence of sickness, malaise and disorder, and can also function as statements confirming that these experiences should be considered integral parts of the subject's life (Tembeck 2008, pp. 87-101). Photographs are narratives that "can insert themselves into a heterogeneous tradition of illness narratives inflecting ongoing questions about the politics of medicine and shaping current debates calling for a more

4 In US popular culture, the so-called "narrative of triumph" has also represented a part of illness narratives. In this kind of narrative, in general, the narrator or protagonist reaches physical health or peace of mind; it is a triumphant ending that makes them a better person than they were before the illness. Arthur W. Frank calls it "restitution narrative" (Frank 1995, p. 77), while G. Thomas Couser describes it as the "culturally validated narrative of triumph over adversity" (Couser 1997, p. 5).

5 In the late twentieth century, illness and disability narratives were established as literary genres that became central to the literary field of medical humanism. See (Whitehead and Woods 2016; Crawford et al. 2020). 
critical medical humanities" (Bolaki 2016, p. 29). Certainly, photographs can transform the sick body into an object of scrutiny and can be used for the surveillance of medical practices (for instance in representations of the mentally ill; (Gilman 1996)), of the techno-scientization of medical care, and of the transformations in the production, distribution and consumption of biomedical knowledge (see (Clarke et al. 2010)). Yet, through photographs—-whether taken by the sick patient themselves or by others (nurses, doctors, caregivers, relatives or friends) — the subject can make themselves visible, as an agent who determines their own exposure, and who intentionally blurs the boundaries between subject and object.

From professional art photographs to vernacular selfies, photographs become "autopathographies" that offer a first-person perspective on experiences of illness or hospitalization (Tembeck 2016). Through these self-representational practices, an embodied experience of illness is transformed into a process of learning that recognizes bodily sensation as constituting valid and forceful knowledge. A well-known example is the work of British photographer Jo Spence, who developed photo therapeutic methods as part of her solo cancer survival program (Dennett 2013). Spence also believed that photographer and viewer share a responsibility to take photographs beyond their frames, to incorporate them into their own experiences, and to connect these experiences with those of other workers, patients, doctors and families (Bell 2002). The indexicality and materiality of the photograph (whether analog or digital) joins the descriptive, physical and graphic qualities of the written word (on paper and screen, as well as on bodies as visible in some of Jo Spence's self-portraits), along with the potential of words to render what cannot be seen, and to introduce "time, consciousness, history and the alienating intervention of symbolic mediation" into the world (Mitchell 1986, p. 43). Together-whether synchronically or diachronically-words and images represent a subject that is to be seen and read as well as touched. In fact, by exposing a wounded body made up of the marks left on its flesh (Kearney 2018), words and images invite the reader-viewer into a kind of haptic relationship, an emotional and sensory encounter.

Through diverse approaches, the articles in this Special Issue explore how the body and its pain and disorders can be accessed in projects that either interlace words and images within themselves or that communicate and interrelate with other written or visual texts produced by others. In these photo-textual encounters (or clashes), wounded, tormented, weakened bodies are narrated and mediated, as well as marked, modified and exposed by personal and emotional choices or by ideological and socio-historical circumstances. Words and images are also often employed as forms of response or resistance to medical discourses and the stigmatization, institutionalization and politicization of illness, and consequently as a means of reclaiming lost subjectivity and corporeality.

In different ways, images and words are inextricably bound. In terms of their social function, all images are constantly infused with writing (Krauss 1984). "Photography," according to Mitchell, "is and is not a language; language also is and is not a 'photography'" (Mitchell 1995, p. 281). Photography blurs the traditional distinction between showing and telling, visual and linguistic signs. For Linda Hutcheon, postmodern photography links verbal and visual discourses to highlight "the theoretical implications of the differences between, on the one hand, meaning-producing within the two separated and differing discourses and, on the other, any meaning created through their interaction" (Hutcheon 2002, p. 133). These implications are not only theoretical but also political, social and ethical, as Mitchell asserts: "[t] he relation of photography and language is a principal site of struggle for value and power in contemporary representations of reality; it is the place where images and words find and lose their conscience, their aesthetic and ethical identity" (Mitchell 1995, p. 281).

In her article titled "Representation of the Self and Disease: Writing, Photography and Video in Hervé Guibert," Marta Sábado Novau discusses the tensions between and mutual complementarity of words and images in the works of French writer and photographer Hervé Guibert and his intensive self-examination of his own body and of the changes imposed on it by HIV. Through writing, photography and video, Guibert carries out a theoretical reflection on the limits of both written and visual language. Sábado shows how Guibert regains power over his experience through writing, as it 
is through writing about illness in a poetic way that he unveils the inside of himself and turns "the passivity imposed by illness into activity". Guibert transposes his fragmented body onto the written text. By so doing, through writing, he is able to regain control of the experience of illness and its consequent disintegration. Words sustain the individual's fantasies and help Guibert find an imaginary continuity and unity in which to unveil his self and body. On the other hand, Sábado also shows how Guibert's photographic self-portraits expose a sense of loss and distress and the impossibility of representing that same body. Guibert thus transposes his search for a suitable means of self-narration to his video and multimedia experimentations, wherein words and images can compromise and collaborate in order to express a sense of unaccountable time and, therefore, of death (Sábado).

In most of the works discussed in this Special Issue, we can see these continuous acts of connection and transference. Rosi Braidotti uses the term "transposition" to explain a sense of fluid "interconnection" that occurs at a human level through different modes of representations. In fact, Braidotti suggests an ethical non-unitary view of the subject that "proposes an enlarged sense of interconnection between self and others, including the non-human or 'earth' others, by removing the obstacle of self-centred individualist" (Braidotti 2006, p. 35). Transposition in particular "indicates an intertextual, cross-boundary or transversal transfer, in the sense of a leap from one code, field or axis into another" (Braidotti 2006, p. 5). In the varied works discussed herein, transposition and connection happen between writing and visual images (whether they are made by one person or by different individuals or groups), as well as between authors and artists or practitioners and readers-viewers. As such, in "Exploring Intimacy in Collaborative Photographic Narratives of Breast Cancer", Agnese Sile explores how couples make sense of and communicate illness through photographs and written texts that articulate and mediate private experiences. In the works that Sile examines, photographs and their accompanying written texts allow experiences of breast cancer to sustain intimacy. They also have the power to motivate the participants in the photographic act and to make their stories public. Collaborative photo-textual works thus turn the individual illness condition into a politicized collective one, affirming that illness, rather than being solely an individual experience, cannot be separated from the physical, social and cultural environment (Sile).

In these dialogues between written texts and visual images, otherwise known as intermedial texts or "iconotexts" (Wagner 1995), photographs and other images together with words often tell different stories. Louvel (2011, p. 15), for instance, theorizes the "iconotext" as an in-between object wherein text and image "merge in a pluriform fusion", while nevertheless maintaining their specificities. Yet visual representation incorporates textuality, and in many ways, words are like pictures, so the two modes cannot be clearly separated. For Mitchell, "the medium of writing deconstructs the possibility of a pure image or pure text, along with the opposition between the 'literal' (letters) and the 'figurative' (pictures) on which it depends". The physical and graphic form of writing embodies just such an indissoluble joining of the visual and the verbal (Mitchell 1995, p. 95). Whether in the in-between space or in the impure and heterogenous representational practice created by the unintentional or calculated (no)encounters between the two modes, illness and disease may find a powerful place in which to be mediated and translated, although with incongruities, ambiguities and limitations.

The temporal uncertainties of illness, in particular, invalidate not only the patient's hold on futurity and agency but also that of the carer. In "Temporality and the Carer's Experience in the Narrative Ecology of Illness: Susan Sontag's Dying in Photography and Prose," Yianna Liatsos discusses Annie Leibovitz's photographs of Susan Sontag in A Photographer's Life 1990-2005 (2006) and David Reiff's Swimming in a Sea of Death: A Son's Memoir (2008), both published after Sontag's death from myelodysplastic syndrome (MDS) in 2004. These works by Sontag's lover and son, respectively, are read as narratives of two diverse temporal perspectives: that of living through illness and that of remembering terminal time. As Liatsos explains, Leibovitz's and Reiff's visual and written memoirs allow us to ponder the limits of narrating illness from the perspective of the primary caregiver, the one who deals with the conflicting reality of living through prognostic time, and who has to come to terms with its consequences (Liatsos). 
As already mentioned, however, visual and written narrations of illness are not always immune to political, economic or ideological implications that can accentuate the fragility of the subjects narrated. On this topic, in "Photo-Textual Relations: Emphasizing Vulnerability to Efface AIDS," Victoria Oana Lupaşcu considers the relationship between photojournalism and literature about HIV/AIDS in Romania during the late 1980s and 1990s. Lupaşcu examines the ways in which photo-textual relations localize and perpetuate a specific ideological understanding of the AIDS epidemic. Lupaşcu looks at photographs of children suffering from AIDS, taken by French photographer Frank Fournier in Constanța in 1989, and examines them alongside Nobody's Angels. My Life Alongside Children Living with AIDS (2007), the (semi)autobiography by Romanian pediatrician Rodica Mătușa. By looking at these two projects, we can see that photographs and written text worked to efface the sufferers' subjectivity and instrumentalized the epidemic in order to comment on the communist regime's effects on Romanian society. It is a type of interconnection that imposes a methodology of looking, of reading and seeing that, as the author argues, "instrumentalizes and localizes the AIDS epidemic by emphasizing vulnerability" (Lupaşcu).

These photo-textual interrelations and narratives also construct meaning about illness by evoking and interweaving other forms of images (i.e., sensory images) and media. Words and images interact in multiple ways, and not necessarily within the same text, thus allowing the verbalization and visualization not only of those feelings and thoughts which have remained unspeakable, but also of economic and biopolitical dynamics. In the article "Somatic Narratives about Illness. Biometric Visualization of Diseased and Disabled Bodies in Art and Science Projects", Ewelina Twardoch-Raś discusses a sophisticated form of interrelation and transposition between image and text. The focus of her study is artistic projects that are products of various medical imaging methods (X-ray imaging, computed tomography, magnetic resonance imaging, ultrasound and endoscopic examination) and functional imaging (functional magnetic resonance imaging), as well as bio-tracking technologies. They reflect on the impact of the development of medicine on human and non-human life. What emerges in these projects is the problem of the institutionalization of medical practices and the medicalization of life, as well as the issue of how disease and health are continuously socio-culturally re-defined in our contemporary world. These intermedial artistic works point to the multifaceted entanglements of biological life in a variety of biopolitical mechanisms that are mostly economically motivated. Yet belonging to the domain of engaged art, they aim to convey a critical reflection on the biological parameterization of the body and provide empathic narratives of injured and diseased individuals (Twardoch-Raś).

\section{Writing and Visualizing Illness Now}

Coincidently, this Special Issue on illness, writing and photography has been completed during the COVID-19 pandemic. In the past few months, words and images have shown, mediated and attempted to translate the fear, disorder and losses caused by a global disease whose medical, scientific, political and socio-economic consequences are difficult to explain, and that has forced us to confront questions of human existence. Literature of the past on plagues and devastation-from Giovanni Boccaccio's The Decameron (1353) and Daniel Defoe's A Journal of the Plague Year (1722), to Albert Camus's The Plague (1947) and Margaret Atwood's The Year of the Flood (2009)-has been reconsidered and reread according to the recent situation. In turn, distressed faces and bodies and deserted cities have been compared to those depicted in visual images pertaining to similar past situations, such as the 1918 influenza pandemic, in an attempt to find answers to current events. Human and non-human subjects (including highly technical renderings of the virus itself) have been shown, seen, told and read in live blogs, minute-to-minute online and press reports, Instagram photographs and social media entries, coronavirus diaries and obituaries in local newspapers. Stories of people in intensive care, "triumph stories" of those recovering at home, stories of overburdened hospitals and exhausted medical staff, along with pictures of people seen through windows and shared videos of quarantined people telling tales of their lives in isolation, have reported life and death, survival, isolation and 
community, together with other intermedial forms aimed at controlling the disease, such as alert-style updates on mobiles, interactive maps and tracing apps. In multifaced manners, these variated modes have all been narrating and sharing the physical and psychological distress of experiencing illness and the anxieties related to social distancing and the new taboo of touching ${ }^{6}$, as well as monitoring, surveilling and classifying illness. With its "drama of the body," as proclaimed by Virginia Woolf, illness has indeed entered a daily life of solitude, fever and melancholia. Global storytelling and experience-sharing have created a collective photo-textual album wherein domestic and public life, individual actions and community spirit are told and unraveled. Yet, as Susan Sontag argued, illness has no "meaning," and interpreting it runs the risk of stigmatizing its sufferers, particularly if they are represented in some way as "other," such as foreign, non-white, weak or ageing. It is, therefore, also in view of the extraordinary time in which we are living that the articles in this Special Issue invite us to reflect on the ideological discourses, issues of power, practice, ethics and agency that any illness implicates, as well as the flexible boundaries of the written and visual language narrating such an overpowering experience.

Funding: This research received no external funding.

Conflicts of Interest: The author declares no conflict of interest.

\section{References}

A Journal of the Plague Year. n.d. Available online: https://covid-19archive.org/s/archive/page/Share (accessed on 3 June 2020).

Avrahami, Einat. 2007. The Invading Body: Reading Illness Autobiographies. Charlottesville: University of Virginia Press.

Bell, Susan E. 2002. Photo Images: Jo Spence's Narratives of Living with Illness. Health 6: 5-30.

Bell, Susan E. 2006. Living with Breast Cancer in Text and Image: Making Art to Make Sense. Qualitative Research in Psychology 3: 31-44. [CrossRef]

Bevan, David, ed. 1993. Literature and Sickness. Amsterdam-Atlanta: Rodopi.

Bolaki, Stella. 2016. Illness as Many Narratives: Arts, Medicine and Culture. Edinburgh: Edinburgh University Press. Braidotti, Rosi. 2006. Transpositions: On Nomadic Ethics. Cambridge: Polity Press.

Burns, Stanley B. 2007. Seeing Insanity: Photography and the Depiction of Mental Illness. New York: Burns Archive Press. Cavarero, Adriana. 2000. Relating Narratives: Storytelling and Selfhood. Translated by Paul A. Kottman. New York: Routledge.

Chiara Mac Call Photography. n.d. Available online: https:/www.facebook.com/chiaramaccallphotography/ (accessed on 1 May 2020).

Clarke, Adele E., Laura Mamo, Jennifer Ruth Fosket, Jennifer R. Fishman, and Janet K. Shim, eds. 2010. Biomedicalization: Technoscience, Health, and Illness in the U.S. Durham and London: Duke University Press.

Conway, Kathlyn. 2007. Beyond Words: Illness and the Limits of Expression. Albuquerque: University of New Mexico Press.

Coronavirus Diaries. n.d. Financial Times. Available online: https://www.ft.com/coronavirusdiaries (accessed on 3 June 2020).

Corriere della Sera. 2020. Le foto di Marco Di Grazia: «Siamo infermieri e non eroi». April 3. Available online: https://milano.corriere.it/notizie/cronaca/20_aprile_13/marco-di-grazia-infermiere-chefotografa-suoi-colleghi-il-mio-diario-fatto-sguardi-a267c5a6-7dac-11ea-bfaa-e40a2751f63b.shtml (accessed on 1 May 2020).

6 Examples include Chiara Mac Call's series of photographs of people behind windows (Chiara Mac Call Photography n.d.) and the photographs taken by nurse Marco Di Grazia of other nurses (Corriere della Sera 2020). See, also, the Financial Times's "Coronavirus Diaries" project (Coronavirus Diaries n.d.) and other initiatives started in universities and institutions inviting the public to share their experiences of the pandemic, such as "A Journal of the Plague Year" (A Journal of the Plague Year n.d.). 
Couser, G. Thomas. 1991. Autopathography: Women, Illness, and Lifewriting. a/b: Auto/Biography Studies 6: 65-75. [CrossRef]

Couser, G. Thomas. 1997. Recovering Bodies: Illness, Disability, and Life Writing. Madison: The University of Wisconsin Press.

Crawford, Paul, Brian Brown, and Andrea Charise, eds. 2020. The Routledge Companion to Health Humanities. London and New York: Routledge.

DasGupta, Sayantani, and Marsha Hurst, eds. 2007. Stories of Illness and Healing: Women Write Their Bodies. Kent: Kent State University Press.

Dennett, Terry. 2013. Jo Spence's Camera Therapy: Personal Therapeutic Photography as a Response to Adversity. In Phototherapy and Therapeutic Photography in a Digital Age. Edited by Del Loewenthal. New York: Routledge, pp. 31-39.

Diedrich, Lisa. 2007. Treatments: Language, Politics, and the Culture of Illness. Minneapolis: University of Minnesota Press.

Frank, Arthur W. 1995. The Wounded Storyteller: Body, Illness, and Ethics. Chicago: University of Chicago Press.

Gilman, Sander L. 1996. Seeing the Insane. Lincoln and London: University of Nebraska Press.

Gonzalez-Polledo, E., and Jen Tarr. 2014. The Thing About Pain: The Remaking of Illness Narratives in Chronic Pain Expressions on Social Media. New Media E Society 18: 1455-72.

Harper, Graeme, and Andrew Moor, eds. 2005. Signs of Life: Cinema and Medicine. London and New York: Wallflower Press.

Healy, Margaret. 2001. Fictions of Disease in Early Modern England: Bodies, Plagues and Politics. New York: Palgrave. Hinson, Katrina, and Ben Sword. 2019. Illness Narratives and Facebook: Living Illness Well. Humanities 8: 106. [CrossRef]

Hutcheon, Linda. 2002. The Politics of Postmodernism, 2nd ed. New York: Routledge.

Illouz, Eva. 2008. Saving the Modern Soul: Therapy, Emotions, and the Culture of Self-Help. Berkeley: University of California Press.

Jurecic, Ann. 2012. Illness as Narrative. Pittsburgh: University of Pittsburgh Press.

Kearney, Richard. 2018. Working Through Trauma: Narrative Writing Trauma: Catharsis in Joyce, Shakespeare and Homer. ABC Religion and Ethics. Available online: https://www.abc.net.au/religion/working-throughtrauma-narrative-catharsis-in-joyce-homer-and-sh/10094622 (accessed on 21 July 2020).

Krauss, Rosalind. 1984. A Note on Photography and the Simulacral. October 31: 49-68. [CrossRef]

Lawlor, Clark. 2007. Consumption and Literature: The Making of the Romantic Disease. New York: Palgrave.

Loewenthal, Del, ed. 2013. Phototherapy and Therapeutic Photography in a Digital Age. New York: Routledge.

Louvel, Liliane. 2011. Poetics of the Iconotexts. Edited by Karen Jacobs. Translated by Laurence Petit. Farnham: Ashgate.

Mitchell, W. J. Thomas. 1986. Iconology: Image, Text, Ideology. Chicago and London: University of Chicago Press.

Mitchell, W. J. Thomas. 1995. Picture Theory. Chicago and London: University of Chicago Press.

Outka, Elizabeth. 2020. Viral Modernism: The Influenza Pandemic and Interwar Literature. New York: Columbia University Press.

Radley, Alan. 2009. Works of Illness: Narrative, Picturing and the Social Response to Serious Disease. Ashby-de-la-Zouch: InkerMen Press.

Reagan, Leslie J., Nancy Tomes, and Paula A. Treichler, eds. 2007. Medicine's Moving Pictures: Medicine, Health, and Bodies in American Film and Television. Rochester: University of Rochester Press.

Rothman, Sheila. 1994. Living in the Shadow of Death: Tuberculosis and the Social Experience of Illness in America. New York: Basic Books.

Scarry, Elaine. 1985. The Body in Pain. Oxford: Oxford University Press.

Sendra, Anna, and J. Farré. 2020. Communicating the Experience of Chronic Pain through Social Media: Patients' Narrative Practices on Instagram. Journal of Communication in Healthcare 13: 46-54. [CrossRef]

Shell, Marc. 2005. The Paralysis of Culture: Polio and Its Aftermath. Cambridge and Massachusetts: Harvard University Press.

Sontag, Susan. 1978. Illness as Metaphor. New York: Farrar, Straus and Giroux.

Sontag, Susan. 1989. AIDS and its Metaphors. London: Penguin.

Squier, Susan Merrill. 2007. Beyond Nescience: The Intersectional Insights of Health Humanities. Perspectives in Biology and Medicine 50: 334-47. [CrossRef] [PubMed] 
Squiers, Carol. 2005. The Body at Risk: Photography of Disorder, Illness, and Healing. New York: International Center of Photography.

Tembeck, Tamar. 2008. Exposed Wounds: The Photographic Autopathographies of Hannah Wilke and Jo Spence. RACAR: Revue d'art Canadienne/Canadian Art Review 33: 87-101.

Tembeck, Tamar. 2016. Selfies of Ill Health: Online Autopathographic Photography and the Dramaturgy of the Everyday. Social Media + Society 2: 1-11. [CrossRef]

Wagner, Peter. 1995. Reading Iconotexts: From Swift to the French Revolution. London: Reaktion Books.

Whitehead, Anne, and Angela Woods, eds. 2016. The Edinburgh Companion to the Critical Medical Humanities. Edinburgh: Edinburgh University Press.

Wijdicks, Eelco FM. 2020. Cinema, MD: A History of Medicine on Screen. Oxford: Oxford University Press.

Woolf, Virginia. 1926. On Being Ill. The New Criterion 4: 32-45. [CrossRef]

Yudkoff, Sunny S. 2018. Tubercular Capital: Illness and the Conditions of Modern Jewish Writing. Stanford: Stanford University Press.

(C) 2020 by the author. Licensee MDPI, Basel, Switzerland. This article is an open access article distributed under the terms and conditions of the Creative Commons Attribution (CC BY) license (http://creativecommons.org/licenses/by/4.0/). 